\title{
ReSEARChArTicle
}

\section{Study on selection parameters for yield components in yellow sarson (Brassica rapa var. yellow sarson)}

\author{
KUMARI SHANTI, KAMLESH KUMAR, POORAN CHAND AND KRISHNA KUMARI
}

\begin{abstract}
SUMMARY
An experiment was conducted to assess the genetic variability, heritability and genetic advance duringRabi-2012-13 at N.D.U.A. and T., Faizabad with forty four germplasm of yellow sarson. The data were recorded on 13 characters days to $50 \%$ flowering, days to maturity, plant height $(\mathrm{cm})$, primary branches per plant, length of main raceme $(\mathrm{cm})$, number of siliquae on main raceme, number of seeds per siliqua, length of siliqua $(\mathrm{cm})$, biological yield $(\mathrm{g})$, seed yield per plant $(\mathrm{g})$, harvest index (\%), 1000-seed weight (g) and oil content (\%). The highest estimates phenotypic (PCV) and genotypic $(\mathrm{GCV})$ co-efficient variation were found in plant height $(\mathrm{cm}) \mathrm{PCV}=52.81$ per cent, $\mathrm{GCV}=41.73$ per cent. The lowest value of PCV and GCV was recorded for siliqua length $(\mathrm{PCV}=0.14 \%, \mathrm{GCV}=0.06 \%)$, the value of heritability $\left(\mathrm{h}^{2} \mathrm{~b}\right)$ ranged from 15.56 (oil content) to 92.32 per cent (days to $50 \%$ flowering). Higher estimates of heritability were observed for days to 50 per cent flowering, primary branches $(87 \%)$, seed yield/plant $(88.11 \%)$ and plant height $(79.03 \%)$ genetic advance in per cent of mean was exhibited highest for primary branches per plant $(49.07 \%)$ and lowest for oil content $(0.55 \%)$.
\end{abstract}

Key Words : Yellow sarson, Genotypes and phenotypes co-efficient of variation, Heritability and genetic advance in percentage of mean

How to cite this article : Shanti, Kumari, Kumar, Kamlesh, Chand, Pooran and Kumari, Krishna (2017). Study on selection parameters for yield components in yellow sarson (Brassica rapa var. yellow sarson). Internat. J. Plant Sci., 12 (2): 196-200, DOI: 10.15740/HAS/IJPS/12.2/196-200.

Article chronicle : Received : 01.05.2017; Revised : 18.05.2017; Accepted : 06.06.2017

\footnotetext{
$\longrightarrow$ MEMBERS OF THE RESEARCH FORUM

Author to be contacted :

KAMLESH KUMAR, Department of Genetics and Plant Breeding, N.D.

University of Agriculture and Technology, FAIZABAD (U.P.) INDIA

Email : dansingh002@ rediffmail.com
}

Address of the Co-authors:

KUMARI SHANTI, Division of Genetics, IARI, NEW DELHI (INDIA)

$\overline{\text { POORAN CHAND, Department of Genetics and Plant Breeding, Sardar }}$ Vallabhbhai Patel University of Agriculture and Technology, MEERUT (U.P.) INDIA

KRISHNA KUMARI, Department of Botany, C.C.S. University, MEERU (U.P.) INDIA 